\title{
ECONOMIC GLOBALISATION AND ECONOMIC JUSTICE: COVENANTING FOR ACTION BETWEEN THE REFORMED CHURCHES OF South Africa and Germany
}

Author:

Malcolm Damon ${ }^{1}$

\author{
Affiliation: \\ ${ }^{1}$ Economic Justice \\ Network, Fellowship of \\ Christian Councils in \\ Southern Africa, \\ South Africa
}

Correspondence to:

Allan A. Boesak

e-mail:

boesak@mweb.co.za

Postal address:

Postnet Suite 285, Private Bag X15, Somerset West, 7130, South Africa

\section{Keywords:}

economic globalisation:

economic justice;

Reformed churches

of South Africa and

Germany; ethical moral

formation; globalisation and faith

\section{Dates:}

Received: 21 Aug. 2008

Accepted: 10 June 2009

Published: 06 Nov. 2009

How to cite this article:

Damon, M., 2009,

'Economic globalisation

and economic justice:

Covenanting for action

between the Reformed

churches of South Africa

and Germany', HTS

Teologiese/Theological

Studies 65(1), Art. \#282, 4

pages. DOI: $10.4102 /$ hts.

v65i1.282

\section{This article is available}

at:

http://www.hts.org.za

(C) 2009. The Authors.

Licensee: OpenJournals

Publishing. This work

is licensed under the

Creative Commons

Attribution License.

\section{ABSTRACT}

The premise of this article is that ethical moral formation or 'covenanting for justice' leads to action. The covenanting church itself, in conjunction with other movements, works for justice in all areas of life. The article uses the six aspects of ethical moral formation of Heinz Tödt to analyse some aspects of economic globalisation in order to form moral judgements that will lead to joint action. These six aspects are: assessing the problem as a moral issue; analysing the problem to determine to what extent it challenges the affected; weighing different behavioural responses to the problem; ascertaining what norms, goods and perspectives could play a role in the different moral choices; communicating ethical decisions to stakeholders; and the moral decision and actions themselves.

\section{INTRODUCTION}

The initial subtitle of this article was 'Cape Town to Frankfurt, via Accra'. By means of the metaphor of air flights, I intended to explain the connection and interconnectedness between South Africa and Germany within the framework of globalisation and faith. The direct flight serves as a visible and experiential reminder of the connection between our continents. This link is colonial or historical, political, economic and social. It is Rhenish (Reformed), Lutheran and Moravian. The Accra Confession (WARC 2004) provides the Reformed confessional link as well as the current framework and imperative for our joint deliberations, ethical considerations or judgements, and action.

However, after much discussion and reflection the current subtitled emerged: 'Covenanting for action between the Reformed churches of South Africa and Germany'. The emphasis in this subtitle on 'action' refers to seeking ways of acting together and seeking stronger ways of confessing our role as believers together in the face of economic globalisation.

The premise of this article is that ethical moral formation or 'covenanting for justice' should, in obedience to Christ, lead to action. The covenanting church, along with other movements, works for justice in all areas of life. The Accra Confession states that we will covenant together in obedience to God 'to work for justice in the economy and the earth both in our common global context as well as our various regional and local settings'. This article uses the six aspects of ethical moral formation of Tödt (1988:29-41) in order to analyse some aspects of economic globalisation and to form moral judgements that may lead to joint action.

\section{TÖDT AND ETHICS OF LIFE}

In my thesis titled 'Economic justice for all' (Damon 1995:163-175), the aspects, Sachmomente or Schritte of Heinz Tödt (1988), are applied to the ministry of the then NG Sendingkerk regarding economic justice. Tödt indicates the following six aspects of the ethical moral process:

- $\quad$ assessing and determining the problem as a moral issue

- determining to what extent the problem challenges the affected

- weighing the different behavioural responses to the problem

- ascertaining what norms, goods and perspectives could play a role in the different moral choices

- communicating ethical decisions to stakeholders

- the moral decision and actions themselves.

In the process of moral formation, Tödt (1988:29) emphasises, there is constant interaction between the different aspects. The six aspects do not prescribe a fixed methodology or constitute an 'ideal plan'. They are neither a chronological nor a psychological process. In this article I utilise some of Tödt's aspects in order to critique churches' approach and attitude to economic justice.

Firstly, I will define and analyse the most important aspects of economic globalisation and how they impact on the world today, especially in relation to Africa. Secondly, I will interpret the current norms and values that are applied to economic globalisation and emphasise the importance of action in both South Africa and Germany. The threefold method of observation, interpretation and action has been used extensively in the process of 'covenanting for justice'.

Previously I focused on the process of confessing, the status of confessions, and the Belhar Confession. In this article I utilise the method of observation, interpretation and action, which I find to be especially useful, in the area of moral formation and action.

\section{ECONOMIC GLOBALISATION}

The current state of research displays a great variety of understanding and interpretation of globalisation with its political, economic, social, cultural and technological aspects. Kohler referred to these aspects in the 'encounters' between the World Council of Churches and the International Monetary Fund 
(IMF) and the World Bank. For the purposes of this article I will restrict myself to the financial, trade and institutional aspects of economic globalisation.

\section{FINANCIAL ARCHITECTURE}

The Accra Confession describes neo-liberal economic globalisation with its values of 'capital speculation, deregulation of markets, privatisation, unrestricted foreign investment and free movement of capital for excessive wealth creation'.

The world is choked by a 'casino economy' where trillions of dollars are traded over the Internet, moving from one country to the other, from Lagos to Lichtenstein, from one company to another (or even within companies) and from one computer to another. More than two trillion dollars are shifted in this manner - not for investment in a living economy, but for speculation by financial investors. A recent business newspaper cites speculation as one reason for the current oil price, which is hovering around US\$135 a barrel. In fact, the first time the oil prize broke the US\$100 mark, it was as a result of speculation rather than based on actual trade. In other words as a form of game, one could say. The activities of George Soros and his speculation with regard to the weakening of the pound and the shifting of money from the pound to the Deutsche Mark, led to a major European financial crisis in the 1990. In South Africa, during the first democratic government, there was a rumour that Nelson Mandela was sick or stepping down. That led to a shocking weakening of the rand and to records lows of the rand against the dollar. These are but some of the manifestations of neo-liberal economic globalisation.

A second aspect of neo-liberal economic globalisation is the debt of poor, developing countries, also called 'countries of the global South', more in a political than a strictly geographical sense.

\section{DEBT AND POLITICAL DOMINATION}

Total external debt for sub-Saharan Africa increased from US\$ 84.1 billion in 1980 to US\$ 226 billion in 1995, with a debt service ratio of $14.5 \%$ (up from $9.8 \%$ in 1980). In 1999 it was calculated that 41 African countries pay an average of $18 \%$ of their revenues to debt servicing. This debt occurred mostly between 1970 and 1985. Africa's external debt in 2002 was US\$ 295 billion. In the time of the Cold War money was given to African governments in relation to their alliance with the United States of America or the Soviet Union. Political destabilisation and civil war were encouraged as for example was the case in Mozambique with its Renamo faction. Renamo was supported financially by the Central Intelligence Agency (CIA) and the apartheid South African government in order to oppose the socialist state of Mozambique. At the same time, a high percentage of government spending was on the military and weapons. In the 1970s the World Bank lending to African developing countries increased five-fold. Loans were used for capital-intensive infrastructural development such as dams and roads, as well as for personal enrichment, as was the case for example with Mobuto Se Seko and Nigerian military dictators.

Since then, Africa has been caught in a debt trap. Between 1982 and 1992, African countries have spent US\$ 101 billion on debt repayment. In spite of this, the burden of debt in sub-Saharan Africa is steadily increasing because of compound interest, the devaluation of local currency and the economic instability of debtor countries. In spite of the Heavily Indebted Poor Countries (HIPC) and the Poverty Reduction Strategy programmes under the auspices of the IMF and the World Bank, the development of Africa is impeded by its burden of debt.

Today most poor countries in Africa have qualified for debt reduction and cancellation. However, the language is still a language of bondage. 'Debt sustainability' refers to the ability of poor countries to avoid the debt trap in future and to repay their debt. In spite of debt reductions, Africa is still transferring more money to rich Western countries than what they received in the form of 'aid' in the first place.

\section{THE ROLE OF THE WORLD BANK AND THE IMF}

The IMF and the World Bank, also called the Bretton Woods Institutions, were formed in 1945 in response to the destruction of two world wars. The founding principles were those of 'value' and 'the common good'. Through the years the focus of these institutions has changed from reconstruction, development (e.g. the Marshall Plan and the rebuilding of Europe and Japan) and monetary relief, to that of control and domination. The World Bank, the major investor in Africa and the global South, provides funding for major projects such as dams, roads and powergeneration infrastructure and it is a dominant resource for knowledge and research in the fields of economics, development and economic globalisation. The governance of these institutions is controlled by Washington and Europe, who hold the majority shares in the World Bank group and the IMF. They also drive, control and interfere in the national policies of governments of the South (Stiglitz 2002:42). As Gilpin (2001:314) notes, '[t]he doctrine of structural adjustment meant that a debtor country applying for financial assistance from the IMF and/or World Bank had to commit itself to a number of stringent economic and structural reforms'. Instead of improving the economic condition of poor countries, these 'reform policies' have led to more poverty and increased economic instability. The new poverty-reduction strategy policies of these institutions still give the IMF and the World Bank the veto to override the policies of poor developing countries. The Poverty-reduction Strategy policy and papers developed by the countries themselves in collaboration with other civil society stakeholders are still to be placed within the policy framework of the institutions of the Washington consensus model - a model based on a neo-liberal economic paradigm.

According to the Accra Confession (2004:par. 13), financial institutions such as the World Bank and the IMF are controlled by the USA and their allies in order to promote and protect the interest of the owners of capital. These institutions are controlled by national governments, including the G8. Germany, as a founding member of the IMF and the World Bank and as part of the European Union (EU), is a significant role-player in these institutions. South Africa, although not a major role-player, can play a more significant role through Trevor Manuel, who is one of the governors within these institutions. South Africa, as a major economic force in Africa, should play a more crucial role. Patrick Bond (2003), in his book on global apartheid, provides a more in-depth insight into the role of these institutions and the resistance movements growing across the world in opposition to the Bretton Woods Institutions.

In summary, finance and global capital play a significant role in neo-liberal economic globalisation. The banks, as false prophets, shout poverty, anti-poverty, governance and peace while their actions and policies exacerbate the extreme negative effects of global capital. The Accra document responds to these issues and the horrendous impact of such systems and policies on the poor of the world.

\section{ACCRA, TRADE, AND THE WORLD TRADE ORGANISATION (WTO)}

The Accra Confession (2004:par. 6) refers directly and indirectly to trade within the unjust global economic justice system. It starts very appropriately with the dehumanising slave trade. Accra and Almena were major centres of trade in human lives to satisfy the needs and markets of the British Empire and its allies, including the Netherlands. It further refers to the 'liberalization and deregulation of the market', the privatisation of resources (the WTO General Agreement on Trade in Services has been controversial and is seen as unjust, especially regarding the privatisation of essential services, including water, health care and other common goods of the earth and communities), imports and lowering of taxes (Accra Confession 2004:par. 13) and the commoditisation of natural resources (Accra Confession 2004:par. 12). 
The Accra document refers to the role of the WTO in collaboration with the World Bank and the IMF as they drive the agenda of the 'new empire' and protect the interests of capital owners. Currently trade liberalisation is seen as the engine for Africa's socioeconomic development. Trade liberalisation promotes free trade between countries. Previously, countries protected their vulnerable and infant local industries and tradable products through tariffs and other measures. Free trade promotes and demands lower or no tariffs and the elimination of trade-related constraints so that goods and services can be freely exported and imported between countries. The multilateral WTO was founded in 1995. A total of 147 countries are members of this organisation which regulates trade between member countries. Proponents of trade liberalisation argue that free trade will lead to economic growth, which will again lead to poverty reduction. Research indicates that Africa's contribution to world trade has decreased and free trade has not led to poverty reduction.

The influence, power and dominant role of the WTO has increased tremendously over the past decade. The WTO is the only effective global governance system that, through its court of arbitration, can force countries to adhere to its decisions by giving national governments the power to institute retaliatory measures that can seriously impact on certain sectors of the economy, especially the parties involved in the dispute.

Since the battle in Seattle (Damon 2002) in Washington, this powerful force moved onto the screens of the world and ordinary people took note. Since 1999 social movements have protested against these unjust, constrictive rules during the WTO's biennial conferences (Cancun in Mexico, Hong Kong in China). The conference in Doha was a different matter, because after Seattle the meeting was deliberately moved to this remote country where democracy is non-existent and it was difficult to organise a protest, especially after 9/11.

The WTO operates according to the rules of one country, one vote and most decisions are taken on consensus. This appears to be more democratic than the procedures of other organisations mentioned above. However, in this case 'consensus' simply means the dominance of the powerful countries who bully and force others into adopting policies and rules that will further exacerbate the gap between rich and poor and increase the dominance and power of multinational corporations. Jawara \& Kwa (2003:148-158) provide clear illustrations of these tactics and strategies. The negotiations, which in most cases are held behind closed doors (so-called 'green room discussions'), are dominated by the quad (the USA, the EU, Canada and Japan) who strategically involve some developing countries. South Africa, for example, was invited to chair some of these meetings. This does not detract from the fact that the agenda of rich and powerful countries still receives prominence and is mostly implemented without too much resistance.

The Doha round, the current round of negotiations which was launched in Doha, Qatar, has stalled because the USA and the $\mathrm{EU}$ are unwilling to remove trade-distorting subsidies that put profit and the interests of the big Agro-business above those of the 'little people'.

\section{TRADE AND THE ECONOMIC PARTNERSHIP AGREEMENT (EPA)}

The Doha round, which was designed to help development and developing countries, is now on its deathbed, surrounded by the rich and the powerful who are trying to resuscitate it. In spite of such efforts, the rich North is now using bilateral agreements to conquer new markets and continue with the commoditisation of life and the exploitation of the earth and her resources.

More than three years ago, the European Commission started trade negotiations with more than 75 African, Caribbean and Pacific countries which formerly were colonies. These trade negotiations took place within the framework of the Cotonou agreement, which states that the aim of the EPAs should be 'to integrate African, Caribbean and Pacific countries into the global economy'. This trade discussion is replacing the arrangement that has been in effect for decades, namely that the EU would give special treatment and access to its markets to its former colonies which provided products such as sugar, bananas, coffee, beef and other commodities. Rather than just giving poor countries access to their markets, the EU has pushed these countries to 'reciprocate' by opening up their own markets. According to them, 'trade liberalisation' is the answer in an era of globalisation.

Over the past year, the EU has undermined regional integration, which is important to poorer countries in Africa. The EU has also bullied its former colonies into accepting trade proposals that will lower taxes, which in turn will lead to more poverty, destroy agricultural markets and cash crops, and 'will claim the lives of millions' (Accra Confession 2004:par. 7). African churches, including the AACC, EJN and various other forums have indicated that these negotiations will further destroy Africa's economic development. European governments seem to be deaf to the clear message from the majority of African civil society organisations that EPAs will not lead to development in Africa. ${ }^{1}$ However, the parliament of the Netherlands during the week of 19 May 2008 unanimously requested its cabinet not to accept the EPAs if they do not promote development in Africa. ${ }^{2}$

These issues are raised to emphasise the unjust role of the WTO, as mentioned in the Accra Confession, and to argue that the WTO is not a neutral democratic institution but that the EU and other powerful nations use this and other institutions to further exploit poor countries in the interest of the rich and powerful sectors of their respective economies. An example such as that of EPAs demonstrates that the rich countries will use other negotiating platforms to further entrench their unjust rules and systems in the name of 'development' and 'support'.

\section{CONFESSIONS AND ETHICAL JUDGEMENTS}

Tödt's third and fourth aspects of ethical moral formation refer to the making of ethical choices. Beliefs and values inform choices and judgements. That is why confessions, such as the Belhar Confession and the Accra Confession are important. In South Africa the belief that God is on the side of the poor in a special way forms a basis for coming to certain ethical judgements and decisions for action.

Smit (1984:14-38) provides an elaborate discussion on the role of the Barmen Declaration and the Synod of Dahlem. In his article which discusses the confession that God is in a special way on the side of the poor, he distinguishes between a confession and ethical decisions. The latter may change over time. He further differentiates between a catechism of the heart (Rahner) and a catechism of the book. The catechism of the heart refers to beliefs that people carry in their hearts and lives and which, though they are confessional, are not truly acknowledged for various reasons. In 1984 Smit predicted that the idea that God is in a special way on the side of the poor could become an issue of the heart rather than just something on paper (Smit 1984:72).

The Accra Confession has the possibility of becoming a document that comes from the heart which speaks to the serious concerns raised by economic globalisation. It is clear to me that Accra sees the current signs of our times as a situation in which our faith is at stake. The ignition of the 'process of covenanting' follows in the reformed tradition, where confessing of faith has always been regarded as important. However, Barmen, Ottawa (WARC) and Belhar warn that some are confessing their faith before the living, loving and just God while Rome is burning.

1. The author has raised this issue in various forums in Germany and Brussels, including in advocacy meetings with, among others, officials in the Ministry of Develop

2.See statements on EPAs on the website of EJN at www.ejn.org.za. Also see documents of Kirchliche Arbeitstelle Südliche Afrika, Weed and others. 


\section{COMMUNICATION AND ACTION}

The last two Sachmomente of Tödt need special attention in our deliberations and in our engagement through covenanting for justice. Tödt refers to the communication of moral decisions to the role-players. According to him, the communication of moral decisions does not arise from a natural logic but from a freely connected 'concrete responsible humanity'. Social movements are major role-players in the struggle for a more just world. The World Social Forum demonstrates the commitment and action of these role-players when thousands of people participate and bear the cost of demonstrations at the G8 meetings, whereas others communicate their moral commitments to the rich and powerful. These movements in most cases are a demonstration of 'the collective and associated responsible humanity'. This collective sense of responsibility drives freely associated groups, organisations, non-governmental organisations, churches and church aid agencies to struggle for a more just and responsible system.

Communication within the Reformed family, the ecumenical church, is not enough. Churches in Southern Africa and Western Europe should communicate the contents of the Accra Confession to all who believe that a better world is possible. This world that is suffering and groaning needs action on her behalf. It needs action because we believe that 'God is in a special way, a God of the destitute, the poor, the exploited, the wronged, and the abused' (Ps 146:7-9). God calls for just relationships with all creation, with all life and within all communities.

\section{THE COST OF DISCIPLESHIP}

In the book of the Kirchentag of 2007, which focuses on the theme of human dignity (Würde) and is entitled Die Macht der Würde: Globalisierung neu denken, (Quarch, Lechner \& Spiegel 2007), Bishop Dr Johannes Friedrich makes a contribution with the title: Globalisierung im Licht der Ethik Dietrich Bonhoeffers. He proposes three Wittige, of which the third is important for my conclusion. He notes: 'Menschliche Existenz erfährt williche Erfüllung nur im Leben für Andere. Dietrich Bonhoeffers christliche Ethik hat einen scheinbar 'religiouslosen' Kern. Im Dasein für Andere erfüllt sich die christliche Existenz'.

John de Gruchy quotes the following from a sermon of Dietrich Bonhoeffer, which he delivered at the occasion of the baptism of his godson Dietrich Betge:

Our church, which has been fighting in these years only for its selfpreservation, as though that were an end in itself, is incapable of taking the word reconciliation and redemption to mankind and the world. Our earlier words are therefore bound to lose their force and cease, and our being Christians today will be limited to two things: prayer and righteous action among men. All Christian thinking, speaking and organising must be born anew out of this prayer and action.

(De Gruchy 1986:39)

De Gruchy continues that this focus on prayer and action is the heart of Christian spirituality, 'the spirituality of the kingdom of God and his justice'. Spiritual activism that arises from ethics should lead to deeds, not as an end goal, as Tödt would argue, but as part of an ongoing ethical process. Bonhoeffer's commitment and deliberations on the cost of discipleship informed his actions. Action, after much ethical deliberation, cost him his life.

Today we benefit from globalisation, but we have observed and evaluated the impact of neo-liberal globalisation on humanity and the world. Like Bonhoeffer, thousands of young people let the blood of martyrs such as Hector Petersen (Soweto uprisings in South Africa of 1976 and beyond) feed the tree of resistance. There is a cost. The question is whether Christian believers are willing to be disciples, to make the sacrifice, to pay the price when they set their faith in motion, when they put it into action.

\section{REFERENCES}

Bond, P., 2003, Against global apartheid: South Africa meets the World Bank, IMF and international finance, University of Cape Town Press, Cape Town.

Cloete, G.D. \& Smit, D.J. (eds.), 1984, 'n Oomblik van waarheid: Opstelle rondom die NG sendingkerk se afkondiging van ' $n$ status confessionis en die opstel van 'n konsepbelydenis, Tafelberg, Cape Town.

Damon, M.P., 1995, 'Ekonomiese geregtigheid vir almal: 'n Analise van die pastorale brief van die Noord-Amerikaanse Rooms-Katolieke biskoppe oor die ekonomie van die VSA', MTh thesis, University of the Western Cape.

Damon, M.P., 2000, After the "battle of Seattle": Developing countries press for WTO reforms, viewed n.d., from www.sacc-ct.org. za/ppu_wto.html.

De Gruchy, J.W., 2001, Cry justice: Prayers, meditations and readings from South Africa, Collins Liturgical Publications, London.

Friedrich, J., 2007, 'Globalisierung im Licht der Ethik Dietrich Bonhoeffers', in C. Quarch, S. Lechner \& P. Spiegel (Hrsg.), Die Macht der Würde: Globalisierung neu denken. Im Auftrag des Deutschen Evangelischen Kirchentages, Gütersloh, München.

Gilpin, R., 2001, Global political economy: Understanding the international economic order, Princeton University Press, Princeton.

Jawara, F. \& Kwa, A., 2003, Behind the scenes at the WTO: The real world of international trade negotiations, Zed Books, London.

Mshana, R.R. (ed.), 2003, Wealth creation and justice: World Council of Churches encounters with the World Bank and the International Monetary Fund, World Council of Churches, Geneva.

Smit, D.J. 1984a. '... op 'n besondere wyse die God van die noodlydende, die arme en die verontregte ...', in G.D. Cloete \& D.J. Smit (eds.), 'n Oomblik van waarheid, pp. 60-73, Tafelberg, Cape Town.

Smit, D.J., 1984b, 'Wat beteken status confessionis?' in G.D. Cloete \& D.J. Smit (eds.), 'n Oomblik van waarheid, pp. 14-38, Tafelberg, Cape Town.

Stiglitz, J.E., 2002, Globalization and its discontents, Penguin, London.

Tödt, H.E., 1988, Perspektiven theologischer Ethik, Chr. Kaiser Verlag, München.

Quarch, C. Lechner, S. \& Spiegel, P. (Hrsg.), 2007, Die Macht der Würde: Globalisierung neu denken. Im Auftrag des Deutschen Evangelischen Kirchentages, Gütersloh, München. 